\title{
Differences in Youth Students' Emotional Intelligence from Parent Patterns
}

\author{
Rianto Rianto ${ }^{1}$ Agoes Dariyo $^{1 *}$ \\ ${ }^{1}$ Faculty of Psychology, Universitas Tarumanagara, West Jakarta 11440, Indonesia \\ *Corresponding Author. Email: agoesd@fpsi.untar.ac.id
}

\begin{abstract}
Emotional Intelligence is a set of skill for someone to recognize other's emotion and the person itself. One of the factor that effect emotional intelligence is family. Being a family, the parents need some style to nurture their child and it's called parenting styles. There are four parenting style which is authoritative, authoritarian, permissive, and neglecting. The purpose of this research is to know the difference of emotional intelligence from the parenting styles. This research used 60 subject from the range of age 15 to 18 from random school. The sampling method used in this research is simple random sampling. The instrument that was used was Emotional Intelligence and Parenting Styles Questionnaire (Bagian Riset dan Pengukuran Fakultas Psikologi Universitas Tarumanagara, 2013). It took one month for the process of the research, from May to March. From this research, indicates that there's no difference of emotional intelligence based on each parenting styles
\end{abstract}

\section{Keywords: Emotional Intelligence, Parenting Styles, Adolescent}

\section{INTRODUCTION}

On September 25, 2019, many SMK / SMA students took to the streets to voice their voices regarding the Draft Criminal Code (RKUHP). But in the end, they committed anarchic act, namely burning the police post (Amanaturrosyidah, 2019) [1] and throwing stones and firecrackers at the police (Lova, 2019) [2]. As a result, there were several students who were secured by the security. Among the students who were secured, there were students who were invited by a group of other students who were walking towards the DPR Building (Trengginas, 2019) [3]. According to the Chair of the Indonesian Child Protection Institute (LPAI), Seto Mulyadi, these students only participated based on solidarity with friends (Velarosdela, 2019) [4]. On the other hand, there was news that the students' actions were entered by a third party with other plans. According to the Karopenmas of the Public Relations Division of the National Police Headquarters, Brigadier General Dedi Prasetyo, there were several elements who provoked the demonstrators to take anarchist actions (WE Online Editorial, 2019) [5].

The students are classified as adolescents (Santrock, 2018) [6]. Adolescents, according to Lovell and White, are a time period between puberty and a time emerging as a young adult. It is a time where youth preparing themselves to take a role and responsibility as an adult in their culture (Lovell \& White, 2019) [7]. The students, who carried out a demonstration did indeed inspire their anxiety, but they could not control their emotions, so the teenagers took acts of aggression. This act of aggression shows that the EI (emotional intelligence) of adolescents is low. Based on research conducted by García-Sancho, Salguero, and Fernández-Berrocal (2014) [8], someone who has a high EI will not act of aggression. According to Mayer, Caruso \& Salovey (2000) [9] emotional intelligence is a person's ability to understand the meaning of emotions and relationships, and solve problems based on these emotions. There are four aspects that indicate emotional intelligence, namely regulating emotions, understanding emotions, understanding these emotions, and releasing these emotions (Mayer, Caruso, \& Salovey, 2000). Goleman (2009) [10] argues that human intelligence is influenced by several things, namely from the brain, family and the external environment. The part of the brain called the amygdala is the guardian of the emotions you feel. The emotions that are felt can also hijack the behavior that will be carried out (Goleman, 2009) [11]. There are two main conceptualizations of emotional intelligence proposed by Petrides and Furnham (2003) [12]. They differentiate between EI abilities and EI traits. EI's ability is a cognitiveemotional ability in which it focuses on certain emotional abilities while the trait of EI is emotional self-efficacy where it focuses on self-perception and one's own emotional disposition (Petrides \& Furnharm, 2003) [14]. In addition, Mayer, Caruso, and Salovey (1999) [15] also divide emotional intelligence into four levels, such as: emotional management, emotional perception, emotional understanding, and emotional facilitation (Mayer, Caruso, \& Salovey, 1999) [16]. Apart from the brain, family can also affect a person's emotional intelligence.

According to Sumara, Humaedi \& Santoso (2017) [17] the family is the smallest social unit, and is the primary foundation for children's growth and development. In the family, parents will be the first to educate their children. 
According to Sanders (1997) [18], being a parent is not easy, there are many challenges to be faced. According to Baumrind (1991) [19] there are four parenting styles, namely: authoritative, authoritarian, permissive, rejectingneglecting (Baumrind, 1991) [20]. The parenting style proposed by Baumrind has two dimensions, namely parental response and parental demands. According to Baumrind (in Gafoor \& Kurukan, 2014) [21] parental response is also referred to as parental warmth or acceptance which is defined as the effort given by parents by being supportive and accustomed to their child's needs in order to help develop personality, self-regulation and self-affirmation. Then, parental demands are interpreted as behavioral control from parents who make children connect with the family by supervising, dealing with their children, and using actions to discipline children for children who are not obedient.

A study conducted by Williams, Ciarrochi, and Heaven (2012) [22] suggests that adolescents who are educated by parents with authoritarian parenting have lower adaptability than other parenting styles. Besides the ability to adapt, the ability to achieve goals is also lower than that of adolescents with authoritative parenting styles. the main conceptualization of emotional intelligence proposed by Petrides and Furnham (2003) [23]. They differentiate between EI abilities and EI traits. EI's ability is a cognitiveemotional ability in which it focuses on certain emotional abilities while the trait of EI is emotional self-efficacy where it focuses on self-perception and one's own emotional disposition (Petrides \& Furnharm, 2003) [24]. In addition, Mayer, Caruso, and Salovey (1999) [25] also divide emotional intelligence into four levels, such as: emotional management, emotional perception, emotional understanding, and emotional facilitation (Mayer, Caruso, \& Salovey, 1999) [26]. Apart from the brain, family can also affect a person's emotional intelligence.

Research conducted by Uma in 2013 also found that adolescents with authoritative parents are more socially responsible and also more assertive than adolescents with authoritarian and permissive parenting styles (Uma, 2013) [27]. But research conducted by Joshi and Dutta (2015) [28] found results that were contrary to research conducted by other researchers. The research was conducted in India and the results of the research stated that there was no relationship between parenting styles and adolescent emotional intelligence. This happened because of the globalization brought about by the new millennium which led to changes among Indian families such as family structure, closeness and involvement of parents, as well as more women joining the workforce. In Indian families, cultural adjustments, and the rules determined by parents are the expected behavior of parents, it can be seen from how parents in the east are very rigid and demand obedience as a form of caring and a form of warmth, of course this is very different from western part (Joshi \& Dutta, 2015) [29].

\section{METHOD}

\subsection{Design and Research Participants}

The method used in this research is a quantitative method with a sampling technique, namely simple random sampling. The purpose of this study was to find differences in the emotional intelligence of teenage students in terms of parenting styles. Participants who took part in this study were teenage students who ranged in age from 15 years to 18 years. The gender of the participants was not restricted in this study. The number obtained in this study amounted to 60 people with a note that 10 people were not included in this study because of the type of parenting that could not be categorized.

\subsection{Research Measurements}

\subsubsection{Emotional Intelligence Measurement Reliability Test}

The measuring instrument of emotional intelligence in this study was designed by the Research and Measurement Section of the Faculty of Psychology, Tarumanagara University, based on the 5 dimensions of emotional intelligence by Goleman. The emotional intelligence measurement tool has 60 items with 5 answer choices so that each index ranges from 1-5, subjects are instructed to choose one answer with 5 scale choices according to the Likert scale, namely (a) Strongly disagree (STS), (b) disagree (TS), (c) doubtful (RR), (d) agree (S) and (e) strongly agree (SS).

The first dimension of emotional intelligence is selfawareness. In this dimension, there are 6 positive items, examples of positive item statements in this dimension, namely: When I am angry, I know the cause of my anger, and there are 6 negative items, examples of negative item statements are: I am confused about my reasons for being sad. The initial reliability on this dimension is 0.556 . After items 2, 4, 10, 12 are removed because they have a correlation value below 0.2 , the total reliability contained in this dimension becomes 0.684 .

The second dimension of emotional intelligence is managing emotions. In this dimension, there are 6 positive items and 6 negative items. Examples of positive item statements include: when I'm sad, I still do my responsibilities. Meanwhile, examples of negative statements are: when I am sad, I stop doing any activity. The initial result of reliability in this dimension is 0.556 . After items $13,15,16$, and 22 were removed because they did not exceed the value of 0.2 , the reliability value of this measuring instrument became 0.720 .

The third dimension of emotional intelligence is the motivating oneself. In this dimension, there are 6 positive statement items and 6 negative statement items. Examples of statements for positive items are: I imagine myself successful, while examples for negative statements are: I am lazy to do charity. The final result of reliability from this dimension is 0.802 . 
The fourth dimension in emotional intelligence is empathy skills. This dimension has 6 positive items and 6 negative items. Examples of positive statements in this dimension are: even though I feel the sadness of others, I am able to hold back my emotions, while for negative points, examples of statements are as follows: I am lazy to care about other people. The initial reliability result in this dimension was 0.701 . After omitting items 40, 42, 44, and 46, the total reliability in this dimension becomes 0.822 .

The last dimension contained in emotional intelligence is a handling relationship. There are 6 positive and negative points in this dimension. Examples of positive statements in this dimension are: when I have a problem with my friend, I am able to solve it well. Examples of negative statements in this dimension include: I find it difficult to get along in my environment. The reliability result in this dimension is 0.896 .

\subsubsection{Reliability Test of Parenting Patterns}

The measuring tool for parenting is a development of Baumrind's theory by the Research and Measurement Section of the Faculty of Psychology, Tarumanagara University. The first dimension in the first part of this measure is parenting responsiveness for mothers. In this dimension, it has 8 positive items and 8 negative items. Examples of positive statements on this dimension include: Mother took good care of me. Examples of negative statements in this dimension include: The atmosphere at home became tense because the mother spoke loudly and yelled. The initial reliability result on this dimension was 0.857 . After item 9 is omitted, the reliability result of this measuring instrument is 0.875 .

The second dimension in the first part of this gauge is parenting demandingness for the mother. This dimension has 6 positive items and 6 negative items. Examples of positive statements in this dimension are: Mother monitors my condition when I go out of the house. Examples of negative statements in this dimension are: Mother does not seek my whereabouts when I am outside the house. The initial reliability result of this dimension was 0.726 . After item 24 is omitted, the final reliability result on this dimension is 0.743 .

Then in the second part, the dimension of parenting responsiveness in the father has 8 positive statements and 8 negative statements. An example of a positive statement would be: Dad took good care of me. Examples of negative statements include: The atmosphere at home was tense because my father spoke loudly and yelled. The initial reliability result of this dimension is 0.919 . After omitting the 9 th item, the final reliability result of this dimension is 0.929 .

The second dimension in this second part is parenting demandingness for fathers. There are 6 positive items and 6 negative items in this dimension. An example of a positive statement of this dimension is: my father monitors my condition when I go out of the house. Examples of negative statements on this dimension include: Father does not seek my whereabouts when I am outside the house. The initial reliability result of this dimension was 0.792 . After item 25 is omitted the final reliability result from this dimension is 0.809

\section{RESEARCH RESULTS}

\subsection{Description of Research Participants}

Based on data regarding the gender of the participants, 18 male participants $(36 \%)$ and 32 female participants $(64 \%)$ from a total of 50 participants, the actual data were 60 participants but 10 people were removed from this study due to the care cannot be categorized.

Based on data regarding the age of the participants. Participants aged 15 years were 3 people $(6 \%), 16$ years there were 11 people (22\%), 17 people there were 15 people (15\%), 18 people there were 21 people ( $42 \%$ ) out of a total of 50 people. Based on data regarding the origin of the participating schools, 40 participants $(80 \%)$ came from private schools, 9 public schools (18\%), and 1 homeschooling $(2 \%)$.

\subsection{Hypothesis Test}

In this study, the normality test was calculated using the One-Sample Saphiro-Wilk Test. The normality test of the emotional intelligence variable obtained a value, namely $\mathrm{p}$ $=0.189>0.05$, which means that the value of emotional intelligence was normally distributed. Thus, the data analysis test technique used to analyze is the one-way ANOVA technique. The analysis results showed that the value of $p=0.144$ for mother's parenting and $p=0.225$ for father's parenting on emotional intelligence. Based on these results, it can be concluded that there is no difference between the parenting style and the emotional intelligence of adolescents.

\section{DISCUSSION}

The purpose of this study was to see if there were differences in emotional intelligence among adolescents in terms of parenting styles. However, the results of the data analysis found that there was no difference between adolescent emotional intelligence in terms of parenting styles. Thus, these results are not in line with research by Uma \& Uma (2013) [30]. According to the results of research by Uma and Uma (2013) [31], it was found that differences in emotional intelligence in terms of parenting styles. Authoritative parenting has a more role (influence) on emotional intelligence, compared to other parenting styles (authoritarian and / or permissive). Parents who have authoritative parenting are caring, communicative, and full of warmth to their children, so that they grow up in a comfortable, pleasant and happy atmosphere in their lives. They are trained to understand the emotions of others, and are trained to control emotions well in a family environment, as a result they have good emotional intelligence. In addition, there are several things that need to be studied regarding this research. Emotional intelligence 
is not found in terms of parenting, because there are 2 things, namely peer groups and self-concept.

The first thought is the environmental factor that teenagers have, namely communication patterns. According to research conducted by Fidanianty, Lubis, Puspitawati and Susanto (2016) [32], it was found that the communication patterns carried out by adolescents with their peers had a greater impact than parenting styles for adolescent emotional intelligence. This is because the environment of a teenager is school, from morning to evening. So that the communication carried out by these teenagers is more dominated by their peers than by their parents. Apart from being dominated by school activities, Erikson (in Santrock, 2017) [33] states that adolescents are part of the search for self-identity. The self-seeking process carried out by adolescents involves a lot of friendship with their peers compared to their parents. This is because adolescents want to have emotional independence from their parents, so they hang out with their peers more often. Due to this, the portion of time spent with family is reduced, and is spent more with their peers. This indicates why parenting does not play a role in adolescent emotional intelligence. Apart from communication patterns, the self-concept possessed by adolescents is also a factor. Research conducted by Nur and Ekasari (2008) [34] states that a good self-concept will have a positive impact on emotional intelligence. According to Nur \& Ekasari (2008) [35], self-concept is a description that the individual has of himself. Factors that influence selfconcept are parenting, failure, depression and internal criticism. Self-concept is related to emotional intelligence because self-concept determines how a person behaves and how a person interacts with the environment.

The second thought is the limitations experienced by researchers in conducting this research. The conditions that occur when researchers conduct this research are not conducive to conducting research / go directly to the field. This happened because the corona virus / COVID-19 pandemic was happening. So, researchers could not control the data collection process directly. In addition to the problem of conditions, the data collection process carried out is self-report. Self-reports can produce errors and give incorrect answers (Schwarz in Fakkar, 2016) [36]. The difference in perception when interpreting a statement occurs because of the limitations of researchers in providing explanations to participants (Schwarz in Fakkar, 2016) [37]. Next is the lack of the number of participants, because there were obstacles when disseminating research data (Back \& Ho, 2009) [38]. With conditions in the midst of a pandemic, many schools have eliminated the teaching and learning process so that researchers cannot collect data by visiting schools. This resulted in a very minimal number of participants who took part in this study, namely 60 people. In addition, the appropriate subjects in this study are teenagers or students who are involved with acts of aggression. Back again because the condition of data collection was carried out in a pandemic, so the subjects used were adolescent subjects in general. Suggestions for further research are to pay attention to other variables such as peer influence and adolescent self-concept.

\section{CONCLUSION}

The study, which was conducted, involved 60 teenagers in Indonesia as research participants. This research has been conducted and calculated using one-way ANOVA with a significance of 0.144 for mother's parenting for adolescent emotional intelligence and 0.225 for father's parenting for adolescent emotional intelligence. Based on the results of these data, it can be concluded that there is no difference in emotional intelligence in terms of parenting styles.

\section{ACKNOWLEDGMENT}

Thank you profusely to all parties who have helped carry out this research, namely the Tarumanagara University Research and Community Service Institute who supported the funding for this research.

\section{REFERENCES}

[1] Baumrind, D. (1991). The influence of parenting style on adolescent competence and substance use. The Journal of Early Adolescence, 11(1), 56-95.

[2] Culver, D. (1998, November). A review of Emotional Intelligence by Daniel Goleman: implications for technical education. In FIE'98. 28th Annual Frontiers in Education Conference. Moving from 'Teacher Centered' to 'Learner Centered' Education. Conference Proceedings (Cat. No. 98CH36214) (Vol. 2,pp. 855860). IEEE.

[3] Darling, N. (1999). Parenting Style and Its Correlates. ERIC Digest.

[4] Darling, N. \& Steinberg, L. (1993). Parenting styles as context: An integrative model. Psychological Bulletin, 113 (3), 487-496.

[5] Devi, L., \& Uma, M. (2013). Parenting styles and emotional intelligence of adolescents. The Journal of Research ANGRAU, 41(4), 68-72.

[6] Dinkemeyer, D., Mackay, G., Mackay, J. L., \& Dinkemeyer $\mathrm{Jr}$ (1998). The parents handbook: Systematic training for effective parenting of teenagers. Taylor and Francis: New York.

[7] Firdanianty, N. F. N., Lubis, D. P., Puspitawati, H., \& Susanto, D. (2016). Pola Komunikasi Remaja dan Pengaruhnya terhadap Kecerdasan Emosional Siswa SMA Di Kota Bogor. Jurnal Komunikasi Ikatan Sarjana Komunikasi Indonesia, 1(1), 37- 47. 
[8] García-Sancho, E., Salguero, J. M., \& FernándezBerrocal, P. (2014). Relationship between emotional intelligence and aggression: A systematic review. Aggression and violent behavior, 19(5), 584-591.

[9] Halberstadt, A. G. (1991). Socialization of expressiveness: Family influences in particular and a model in general. Fundamentals of emotional expressiveness, 106-162.

[10] Joshi, D., \& Dutta, I. (2015). A correlative study of mother parenting style and emotional intelligence of adolescent learner. Innovative Space of Scientific Research Journals, 13(1), 145-151.

[11] Kopko, K. (2007). Parenting styles and adolescents. New York: Cornell Cooperation Extension.

[12] Mayer, J. D., Caruso, D. R., \& Salovey, P. (1999). Emotional intelligence meets traditional standards for an intelligence. Intelligence, 27(4), 267-298.

[13] Papalia, D. (2014). Experience human development. McGraw-Hill Higher Education.

[14] Palupi, D. R. (2013). Hubungan Antara Motivasi Berprestasi dan Persepsi Terhadap Pola Asuh Orangtua Dengan Prestasi Belajar Psikologi Angkatan 2010 Universitas Airlangga Surabaya. Jurnal Psikologi Pendidikan dan Perkembangan.Vol. 2, No. 01

[15] Petrides, K. V., \& Furnham, A. (2003). Trait emotional intelligence: Behavioural validation in two studies of emotion recognition and reactivity to mood induction. European Journal of Personality, 17, 39-57.

[16] Redaksi WE Online (2019). Ungkap Biang Kerok Demo Rusuh Mahasiswa dan Anak STM, GelengGeleng Dengernya! https://www.wartaekonomi.co.id/ rad248616/ungkap-biang-kerokdemo-rusuh-mahasiswadan-anakstm-geleng-geleng-dengernya.html

[17] Salovey, P., Mayer, J., \& Caruso, D. (2004). Emotional intelligence: Theory, findings, and implications. Psychological inquiry, 15(3), 197-215.

[18] Sanders, M. R., Turner, K. M., \& Markie-Dadds, C. (2002). The development and dissemination of the Triple P Positive Parenting Program: A multi-level, evidence based system of parenting and family support. Prevention Science, 3(3), 173-189.

[19] Santrock, J.W (2018). Adolescence. Boston: McGraw-Hill.

[20] Sumara, D. S., Humaedi, S., \& Santoso, M. B. (2017). Kenakalan remaja dan penanganannya.
Prosiding Penelitian dan Pengabdian kepada Masyarakat, 4(2). 